\section{Andrii Khrutba, Victor Morozov, Yuliia Khrutha, Valentyna Tkachenko, Roksolana Lysak}

\title{
IMPLEMENTATION OF COMMUNICATION AND INTERACTION MANAGEMENT IN DISTRIBUTED ENVIRONMENTAL PROJECTS
}

The object of research is the management of communication processes that occur between different stakeholders in project activities in the implementation of distributed environmental projects. The research is based on the application of the basic provisions of communication management in project management methodologies, including Green Project Management used to study the features and factors influencing individual processes in distributed environmental projects. The paper also applies the current provisions, methodological approaches to set theory and systems analysis (to formalize management processes, development of system models); classical and applied project management standards; expert evaluation methods for quantitative evaluation of criteria; methods of mathematical modeling, etc. The information base of the research is statistical data on the implementation of projects, the results of own research. The main hypothesis of the study is the assumption that a significant impact on the outcome of the implementation of distributed environmental projects is determined by the successful management of communications between stakeholders in the development and implementation of the project. Because the formation of an effective communication management mechanism in distributed environmental projects ensures the receipt of the project product with minimal risks. The interrelation of management of communications and interactions in the distributed projects and features of application of the concept of Green Project Management for management of nature protection projects is shown. Peculiarities of interaction management in distributed environmental projects are analyzed. The method of interaction management in nature distribution distributed projects is offered. The method of creation of a communication plat form for realization of the coordinated management of communications in the distributed projects is offered. With the help of the method it is possible to coordinate the planned actions of the project participants on a set of compromise and related solutions to implement the tasks that are the best results of the project in accordance with the functions for benefits.

It is shown to increase the efficiency of the interaction management process in distributed environmental projects to ensure effective communication in the interaction of stakeholders in distributed environmental projects under the condition of unclear information about the real state of the level of achievement of stakeholder expectations.

Keywords: distributed projects, interaction management, project communication, environmental projects, Green Project Management concept.

\section{How to cite}

Khrutba, A., Morozov, V., Khrutba, Y., Tkachenko, V., Lysak, R. (2021). Implementation of communication and interaction management in distributed environmental projects. Technology Audit and Production Reserves, 6 (2 (62)), 53-57. doi: http://doi.org/10.15587/2706-5448.2021.245853

\section{Introduction}

The interaction of participants in distributed projects in modern conditions is possible only thanks to the development of information technology. Already today, the process of communication in virtual teams is approaching in terms of time and cost to those in ordinary teams, and sometimes even surpasses them in efficiency. The practice of project and program management shows that with a significant difference in values, stakeholders, as a rule, find it difficult to implement interaction, changing the conflict relationship to synergistic. The idea of applying environmental requirements in project management is proposed in works [1,2].
The GreenPM concept provides for the alignment of project management processes with the environmental consequences of the project, which ensures the achievement of business goals while reducing the negative impact on the environment and is implemented at all stages of the project life cycle [3].

In modern conditions, most large-scale projects are distributed, with distribution in space and in time being a key factor. If the distribution in time is a characteristic feature of any project, then in distributed projects, resources and work are spatially separated, which requires the development of special management methods.

Ideas for distributed projects were proposed in [4], where the principle of three $\mathrm{C}$ is defined as the basis of interaction: 
collaboration, co-creation and curiosity (cooperation, joint creativity and interest). The author of the study [5] considers the following forms of distributed cooperation to be effective: peer-to-peer models, joint scientific research, associations of proactive consumers, platforms for participation; global workshop; wiki jobs.

Consequently, the concept of a «distributed project» assumes that the components of such a project are distributed among themselves, that is, they are distant from each other. It is clear that the functioning of such projects is impossible without effective links between its components. Interaction is based on the procedure for interaction between the components of the system, which are described by a certain set of rules and agreements.

A distributed environmental project (DEP) is a unique activity consisting of subprojects (subprograms) distributed functionally, administratively or geographically. In DEP, human, material and financial resources are allocated for the implementation of activities. This activity is aimed at preserving, rational use and restoration of the state of the environment in the interests of modern and future generations within the limits of cost and in accordance with the terms, quality requirements and an acceptable level of risk.

The use of a mathematical model for managing interactions in environmental distributed projects for social ecological-economic systems will ensure the implementation of coordinated communication management in these projects, coordinate the planned actions of project participants on a variety of compromise and joint solutions to implement tasks that are best for the project's results reflecting their interests. The proposed methods are based on the competence-based approach [6], a mathematical model of the formation and functioning of interactions in distributed projects [7].

Thus, the scientific and practical task of increasing the level of efficiency of communications and interaction of stakeholders in distributed environmental projects considered in the work by developing models and methods for managing communications and interactions in these projects based on GreenPM approaches is relevant. The object of the research is the management of communication processes that arise between different stakeholders of project activities in the implementation of distributed environmental projects. The aim of the study is to develop and implement a method for increasing the level of communication efficiency and stakeholder interaction in distributed environmental projects based on GreenPM approaches.

\section{Methods of research}

The research carried out is based on the application of the approaches described in the works $[6,8]$. The main hypothesis of the study is the assumption that for the practical implementation of effective management of communications and interactions in distributed environmental projects, an important task is to harmonize the values and expectations of all stakeholders, provided there is fuzzy information about their real state. The authors propose a method for managing interactions in distributed environmental projects, which is implemented in three stages.

The first stage involves the creation of a communication platform for the project to distribute information for direct informing of stakeholders. The second step is to determine the level of achievement of the expectations of stakeholders. The third stage involves quantifying the effectiveness of coordinated communications management in distributed environmental projects.

Application of the method for each specific environmental project involves the formation of procedures for information distribution processes to inform stakeholders and a quantitative assessment of the quality of communication management in distributed environmental projects. The result of applying the method is to obtain an integral quantitative assessment of the quality of communications management in distributed environmental projects.

Stage 1. Creation of a communication platform for a distributed project.

The project center forms a communication platform for the distribution of information in the project, defines the logic of the network at least at the level of its functional structure and the composition of resources.

The basis for information distribution processes with direct stakeholder information is a communications management plan for distributed environmental projects, a stakeholder awareness model, and a stakeholder specific values model. Knowledge of the rules for organizing the interaction of various project participants as network elements that form service delivery platforms provides them with flexibility in interacting with network resources.

A model of a communication platform for a distributed project is given in [8]. As noted in [8], in order to optimize communication problems and improve the efficiency of work in teams, it is recommended to: allocate time for meetings with the participation of all team members using a virtual project office. Electronic communication tools such as video conferencing, telecom meetings are capable of providing direct communication between project/project management team members.

Stage 2. Assessment of the level of achievement of the expectations of the stakeholders of the distributed environmental project.

A general information model of the process of «managing stakeholder expectations» is presented in [9]. It should be noted that in the process of managing stakeholder expectations, the communications management plan may be updated. The assessment of the level of achievement of the expectations of the stakeholders of the distributed environmental project is carried out using a matrix diagram, which is a tool for identifying the importance of various links. A matrix diagram is used to represent data (elements) in order to graphically illustrate the logical connections between different elements while simultaneously displaying the importance (strength) of these connections [10,11]. The purpose of the matrix diagram for assessing the level of achievement of stakeholders' expectations is a tabular presentation of logical connections and the relative importance of these connections related to the tasks (problems) of achievement, as well as those expected in interpersonal communications:

- interested parties;

- causes of communication problems;

- the requirements of the established and anticipated needs of stakeholders;

- product characteristics and functions;

- characteristics and functions of processes;

- characteristics and functions of production operations and equipment [12].

On the basis of the matrix diagram of value indicators [9], it is possible to build a matrix of connections 
showing the degree (strength) of the dependence of the criteria from each other, how strong the connections between them are. Let's represent the matrix of links as a matrix diagram for assessing the level of achievement of stakeholders' expectations. In the matrix diagram, achievement of communication expectations between stakeholders is denoted by «1», and the absence - by «0». The matrix diagram template is shown in Fig. 1.

\begin{tabular}{|c|c|c|c|c|c|}
\cline { 2 - 6 } \multicolumn{1}{c|}{} & STAKEH $_{1}$ & STAKEH $_{2}$ & STAKEH $_{3}$ & $\ldots$. & STAKEH $_{i}$ \\
\hline STAKEH $_{1}$ & $* * * *$ & & & & \\
\hline STAKEH $_{2}$ & & $* * * *$ & & & \\
\hline STAKEH $_{3}$ & & & $* * * *$ & & \\
\hline$\ldots$. & & & & $* * * *$ & \\
\hline STAKEH $_{i}$ & & & & & $* * * *$ \\
\hline
\end{tabular}

Fig. 1. Matrix diagram for assessing the level of achievement of stakeholders' expectations

Based on the matrix diagram shown in Fig. 1, it is possible to write connections in the form of directed graphs between stakeholders, where communication is most effective and stakeholders' expectations are achieved.

The relationship between individual stakeholders can be represented by a general assessment model in the form of a directed graph:

$$
G=(V, H),
$$

where $V$ is a finite set of vertices (nodes, points) of the graph, and $H$ is a set of pairs of vertices, that is, a subset of the set $V \times V$ or a binary relation on $V$. Elements of $H$ are edges or links. For an edge $h=(u, v) \in H$, the vertex $u$ is called the beginning of $h$, and the vertex $v$ is called the end of $h$; an edge $h$ leads from $u$ to $v$ [12].

A strongly connected matrix of a directed graph is a binary matrix containing information about all strongly connected vertices in a directed graph. Strongly connected matrix is symmetric. In a strongly connected graph, such a matrix is filled with ones. The connectivity matrix of a graph $G$ is a square matrix $S(G)=\left[S_{i j}\right]$ of order $n$, which elements are equal:

$$
s_{i j}=\left\{\begin{array}{l}
1, \text { if } \exists \text { route, which connect } v_{i} \text { and } v_{j}, \\
0, \text { otherwise }
\end{array}\right.
$$

It is advisable to build a targeted graph $G=(V, H)$ to reflect the assessment of the level of achievement of the expectations of all stakeholders. Let's compose an adjacency matrix (table).

Stage 3. Quantification of the effectiveness of communications management in distributed environmental projects.

The effectiveness of the communication process is determined by the speed of exchange of messages and/or ideas and the degree of achievement of the goal and result.

The efficiency of communications $\left(E_{\text {commun }}\right)$ is determined by the efficiency of using the technological com- ponent $\left(E_{\text {tech }}\right)$, the efficiency of the environment $\left(E_{\text {envir }}\right)$ and the communicative competence of the participants in the communication process $\left(E_{\text {people }}\right)$ :

$$
E_{\text {commun }}=E_{\text {tech }}+E_{\text {envir }}+E_{\text {people }} \text {. }
$$

The technological component of effective communication is assessed based on the results of the analysis of the level of awareness of stakeholders and the availability of communication channels available for use, which include infrastructure, software, material and technical support, linguistic support, organizational and methodological support, etc.

\section{Research results and discussion}

Let's consider the result of applying the method of managing interactions in distributed environmental projects using the example of the project «Environmental strategy of the city of Kyiv until 2030» [13].

Stage 1. Creation of a communication platform for a distributed project.

Main stakeholders of the project:

- initiative group of the project $\left(S t_{1}\right)$;

- communal enterprise «Kyiv City House of Nature»,

Ukraine $\left(S t_{2}\right)$;

- Department of Ecology and Natural Resources in Kyiv, Ukraine $\left(S t_{3}\right)$;

- «Air» direction $\left(S t_{4}\right)$;

- expert of the «Air» direction $\left(S t_{4}^{\exp }\right)$;

- «Green areas and biodiversity» direction Ukraine $\left(S t_{5}\right)$;

- expert of the «Green areas and biodiversity» direction $\left(S t_{4}^{\exp }\right)$;

- «Water» direction $\left(S t_{6}\right)$;

- expert of «Water» direction $\left(S t_{6}^{\exp }\right)$;

- «Science and Education» direction $\left(S t_{7}\right)$;

- expert of the «Science and Education» direction ( $\left.S t_{7}^{\exp }\right)$;

- «Environmental safety» direction $\left(S t_{8}\right)$;

- expert of the «Environmental safety» direction ( $\left.S t_{8}^{\exp }\right)$;

- «Waste» direction $\left(S t_{9}\right)$;

- expert of the «Waste» direction $\left(S t_{9}^{\text {exp }}\right)$.

During the implementation of the project, 15 public meetings were held during the year, to which more than 200 people were involved, during which proposals were developed for each of the areas.

At stage 2, the forecast of the level of achievement of the expectations of the interested parties is determined. Fig. 2 shows the graph of the achievement of stakeholders, which allows to determine the level of communication activity of each stakeholder and form a matrix diagram for assessing the level of achievement of the expectations of stakeholders (Fig. 3).

Fig. 3 shows a matrix diagram for assessing the level of achievement of stakeholders' expectations in the project «Environmental Strategy of Kyiv until 2030».

The analysis of the results obtained allows to quantitatively assess the effectiveness of communications management for the structure that carries out general communications management in the project «Environmental Strategy of Kyiv until 2030».

Stage 3. Quantification of the effectiveness of communications management in distributed environmental projects.

The ranking of efficiency assessment options is based on the values of the vector elements $E_{\text {commun }}$. 


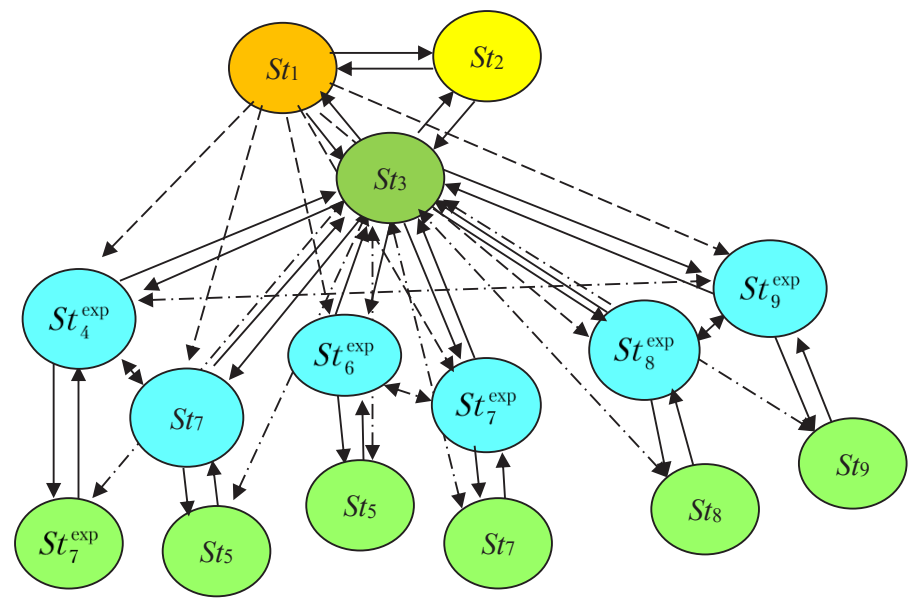

Fig. 2. Graph for the formation of stakeholder communications

\begin{tabular}{|c|c|c|c|c|c|c|c|c|c|c|c|c|c|c|c|c|}
\hline & $S t_{1}$ & $S t_{2}$ & $S_{t}$ & $\mathrm{St}_{4}$ & $S t_{4}^{\exp }$ & St $t_{5}$ & $S t_{5}^{\exp }$ & St 6 & $S t_{6}^{\exp }$ & $S_{t 7}$ & $S t_{7}^{\exp }$ & Sts & $S t_{8}^{\exp }$ & St9 & $S t_{9}^{\text {exp }}$ & Sum \\
\hline$S t_{1}$ & $*$ & 1 & 1 & 1 & 1 & 0.5 & 1 & 0.5 & 1 & 0.5 & 1 & 0.5 & 1 & 0.5 & 1 & 11.5 \\
\hline $\mathrm{St}_{2}$ & 1 & $*$ & 1 & 0 & 0 & 0 & 0 & 0 & 0 & 0 & 0 & 0 & 0 & 0 & 0 & 2 \\
\hline$S t_{3}$ & 1 & 1 & $*$ & 1 & 1 & 1 & 1 & 1 & 1 & 1 & 1 & 1 & 1 & 1 & 1 & 14 \\
\hline $\mathrm{St}_{4}$ & 0.5 & 0 & 1 & $*$ & 1 & 0 & 0 & 0 & 0 & 0 & 0 & 0 & 0 & 0 & 0 & 2.5 \\
\hline$S t_{4}^{\exp }$ & 1 & 0 & 1 & 1 & $*$ & 0 & 0.5 & 0 & 0.5 & 0 & 0.5 & 0 & 0.5 & 0 & 0.5 & 5.5 \\
\hline St5 & 0.5 & 0 & 1 & 0 & 0 & $*$ & 1 & 0 & 0 & 0 & 0 & 0 & 0 & 0 & 0 & 2.5 \\
\hline$S t_{5}^{\exp }$ & 1 & 0 & 1 & 0 & 0.5 & 1 & $*$ & 0 & 0.5 & 0 & 0.5 & 0 & 0.5 & 0 & 0.5 & 5.5 \\
\hline$S t_{6}$ & 0.5 & 0 & 1 & 0 & 0 & 0 & 0 & $*$ & 1 & 0 & 0 & 0 & 0 & 0 & 0 & 2.5 \\
\hline$S t_{6}^{\exp }$ & 1 & 0 & 1 & 0 & 0.5 & 0 & 0.5 & 1 & $*$ & 0 & 0.5 & 0 & 0.5 & 0 & 0.5 & 5.5 \\
\hline$S t 7$ & 0.5 & 0 & 1 & 0 & 0. & 0 & 0 & 0 & 0 & $*$ & 1 & 0 & 0.5 & 0 & 0 & 2.5 \\
\hline$S t_{7}^{\exp }$ & 1 & 0 & 1 & 0 & 0.5 & 0 & 0.5 & 0 & 0.5 & 1 & $*$ & 0 & 0.5 & 0 & 0.5 & 5.5 \\
\hline Sts & 0.5 & 0 & 1 & 0 & 0 & 0 & 0 & 0 & 0 & 0 & 0 & $*$ & 1 & 0 & 0 & 2.5 \\
\hline$S t_{8}^{\exp }$ & 1 & 0 & 1 & 0 & 0.5 & 0 & 0.5 & 0 & 0.5 & 0 & 0.5 & 1 & $*$ & 0 & 0.5 & 5.5 \\
\hline$S t 9$ & 0.5 & 0 & 1 & 0 & 0 & 0 & 0 & 0 & 0 & 0 & 0 & 0 & 0 & $*$ & 1 & 2.5 \\
\hline$S t_{9}^{\exp }$ & 1 & 0 & 1 & 0 & 0.5 & 0 & 0.5 & 0 & 0.5 & 0 & 0.5 & 0 & 0.5 & 1 & $*$ & 5.5 \\
\hline
\end{tabular}

Fig. 3. Matrix diagram for assessing the level of achievement of stakeholders' expectations in the project «Environmental Strategy of Kyiv until 2030»

By combining fuzzy logical equations for all criteria, let's assess the effectiveness of coordinated communication management in distributed environmental projects:

$$
\begin{aligned}
& \mu\left(E_{\text {commun }}\right)=\beta_{1} \cdot \mu\left(E_{\text {tech }}\right)+\beta_{2} \cdot \mu\left(E_{\text {encir }}\right)+\beta_{3} \cdot \mu\left(E_{\text {people }}\right), \\
& \text { in the case of } \sum_{i=1}^{3} \beta_{i}=1,
\end{aligned}
$$

where $\mu$ - degree of belonging of an element to a fuzzy set; $E_{\text {tech }}$ - efficiency of using the technological component; $E_{\text {envir }}$ - efficiency of the environment; $E_{\text {people }}-$ communicative competence of the participants in the process.

According to the methodology for assessing the quality of communications management in distributed environmental projects using a logical conclusion tree of hierarchical relationships of criteria affecting the effectiveness of coordinated communications management in distributed environmental projects, the criteria for assessing the effectiveness of coordinated communications management were evaluated.

The maximum values of clear solutions for the assessment of each parameter were obtained:

$$
\mu\left(E_{\text {tech }}\right)=0.8 ; \mu\left(E_{\text {envir }}\right)=0.7 ; \mu\left(E_{\text {people }}\right)=0.75 \text {. }
$$

The efficiency of coordinated management of communications in distributed environmental projects (formula (3)) is 0.785 .

The effectiveness of communications was confirmed by an increase in the number of solved problems, the number of correctly solved problems, an increase in the number of communications in the network, a reduction in the time for discussion; more electronic group documents.

The calculation of the effectiveness of communications was carried out according to the Harrington desirability scale. The resulting value of 0.785 corresponds to an interval on a scale of $0.8-0.67$ and corresponds to the rating «Good», which confirms the effectiveness of coordinated management of communications in distributed environmental projects.

The results obtained reflect the level of achievement of the expectations of stakeholders in the implementation of the project, which is ensured by the consistency of communication management processes and is a prerequisite for its success. The procedures for distributing information to inform stakeholders formed in the distributed environmental project «Environmental Strategy of Kyiv until 2030» are effective, which is confirmed by the quantitative value of assessing the quality of communication management 
in this project. The application of the developed method made it possible not only to identify the stakeholders of the project, which is a typical stage in the communication management procedure, but also to determine the level of expectations of each stakeholder, its communicative activity and form a matrix diagram of value indicators to assess the level of achievement of these expectations. The obtained quantitative assessment of the quality of communications management in distributed environmental projects confirms the effectiveness of coordinated communications management in the distributed environmental project «Environmental Strategy of Kyiv until 2030».

Evaluation of the effectiveness of communication management in distributed environmental projects is a prerequisite and an important factor in the management of communication processes. It implies the need to select criteria for assessing the effectiveness of communication. Knowing the criteria for assessing the effectiveness of communication, at the planning stage, it is possible to choose the most suitable and effective ways of its implementation. However, the criteria for coordinated communication management are unique for each distributed environmental project, they can be both quantitative and qualitative, and are determined taking into account the specifics of the project and the expectations of stakeholders. Consequently, the direction of further research is the search for a mechanism to formalize these criteria and the development of a unified approach for a quantitative assessment of criteria of different nature in order to improve the efficiency of communication management in distributed environmental projects.

\section{Conclusions}

In the course of the study, a method for managing communications in distributed environmental projects was obtained. This method involves the development of a stakeholder management strategy based on the results of stakeholder identification and the formation of the Register of Stakeholders. The formation of the Register of Stakeholders is carried out with the subsequent planning of the coordinated management of communications based on the determination of the specific values of the stakeholders. The values are formed on the basis of sustainable development indicators. The result of the method is the development of a communication management plan in distributed environmental projects with fuzzy information about the real state of the internal and external interests of the project stakeholders. Criteria for evaluating the effectiveness of the communication environment have been developed.

The results of the study will be useful in planning the management of communications in environmental projects.

\section{References}

1. Krasnoff, A., Mochal, T. Green Project Management: Supporting ISO 14000 Standards Through Project Management Processes. Available at: http://greeneconomypost.com/green-project-management-greenpm-iso-14000-11040.htm
2. McKinlay, M. (2008). Where is Project Management running to...? The official website of the 22nd IPMA World Congress. International Project Management Association. 22nd World Congress. Rome.

3. Randolph, W. A., Posner, B. Z. (1991). Getting the Job Done: Managing Project Teams and Task Forces for Success. Pearson P T R, 142.

4. Fuchs, C. (2008). Wikinomics: How mass collaboration changes everything - by Don Tapscott \& Anthony D. Williams. Journal of Communication, 58 (2), 402-403. doi: http://doi.org/ 10.1111/j.1460-2466.2008.00391_5.x

5. Goodbye Branding (It Doesn't Matter What You Say). Modern Marketing by Collaborate Marketing Services. Available at: https:// www.collaboratemarketing.com/modernmarketing/2007/11/theideanet.html

6. Rukovodstvo $k$ svodu znanii po upravleniyu proektami (2019) Rukovodstvo PMBOK (Rukovodstvo PMBOK). Project Management Institute. Olimp-Biznes, 792.

7. Khrutba, Yu. S., Morozov, V. V., Khrutba, A. S. (2019). Features of interventions of stakeholders in nature-protect projects. Upravlinnia rozvytkom skladnykh system, 37, 32-39.

8. Fesenko, T. H. (2012). Upravlinnia proektamy: teoriia ta praktyka vykonannia proektnykh dii. Kharkiv: KhNAMH, 72-90.

9. Hohunskyi, V. D., Kolesnikov, O. Ye., Kolesnikova, K. V., Yakovenko, V. O., Koliada, A. S., Olekh, T. M. et. al. (2015) Metodolohichni osnovy stvorennia informatsiinoho seredovyshcha upravlinnia naukovymy doslidzhenniamy strukturnykh odynyts VNZ MON Ukrainy. Zvit No. 696-32 (promizhnyi). No. derzhreiestratsii 0115U000330. Odessa: Odeskyi natsionalnyi politekhnichnyi universytet, 145.

10. Khrutba, V., Khrutba, A., Rayets, M. (2018). Project-related approach of communication management in solving local environmental problem. Scientific letters of Academic society of Michal Baludansky, 6 (5), 65-75.

11. Nouler, L., Khauell, Dzh., Gold, B., Koulmen, E., Moun, O., Nouler, V. (1989). Statisticheskie metody kontrolya kachestva produktsii. Moscow: Izd-vo standartov, 96.

12. Olekh, T. M. (2015) Rozrobka modelei tsile pokladannia ta metodiv pryiniattia rishen $v$ proektakh na osnovi bahatovymirnykh otsinok. Odessa, 164.

13. Ekolohichna stratehiia m. Kyieva do 2030 roku (2021). Rishennia Kyivskoi miskoi Rady No. 2399/2440. 23.09.2021. Available at: https://kyivcity.gov.ua/npa/pro_zatverdzhennya_kontseptsi ekologichno politiki mista kiyeva ekologichna strategiya mista_kiyeva_do_2030_roku/wxhcugede5_2399-24440.pdf

Andrii Khrutba, Postgraduate Student, Department of Management Technology, Taras Shevchenko National University of Kyiv, Kyiv, Ukraine, ORCID: https://orcid.org/0000-0003-2456-8437

Victor Morozov, PhD, Professor, Head of Department of Management Technology, Taras Shevchenko National University of Kyiv, Kyiv, Ukraine, ORCID: https://orcid.org/0000-0001-7946-0832

$\triangle$ Yuliia Khrutba, PhD, Associate Professor, Department of Transport Law and Logistics, National Transport University, Kyiv, Ukraine, e-mail: hrutbaj@gmail.com, ORCID: https://orcid.org/0000-00023419-8364

Valentyna Tkachenko, PhD, Associate Professor, Department of Transport Law and Logistics, National Transport University, Kyiv, Ukraine, ORCID: https://orcid.org/0000-0001-5147-0772

Roksolana Lysak, PhD, Associate Professor, Department of Ecology and Life Safety, National Transport University, Kyiv, Ukraine, ORCID: https://orcid.org/0000-0002-2776-5623

$\triangle$ Corresponding author 